Review paper

\title{
About the history of conflicts over urban forestry in Estonian towns
}

\author{
Heldur Sander ${ }^{1, *}$ and Toivo Meikar ${ }^{2}$
}

Sander, H., Meikar, T. 2020. About the history of conflicts over urban forestry in Estonian towns. - Forestry Studies | Metsanduslikud Uurimused 73, 1-25, ISSN 1406-9954. Journal homepage: http://mi.emu.ee/forestry.studies

\begin{abstract}
The article explores conflicts related to forests and parks of Estonian towns from the Middle Ages to the 1940s. A brief overview is first given of the development of urban forestry in Estonia. There are also cases where the loss of urban forests and the related problems that arose could have led to conflicts, but for certain reasons they did not emerge. The main focus of the research is on Tallinn and its nearby island of Naissaare and, to a lesser extent, on the town of Haapsalu. The cases with the probability of conflict are described on the example of Tallinn, Tartu and Pärnu. It is apparent that conflicts or preconditions for their emergence were caused by various reasons, both at the state and town level where local authorities and ownership relations played their role. But the causes of the conflicts can also be traced to the wider clash between military and political causes, economic development and the general public.
\end{abstract}

Key words: green conflicts, urban forests and parks, Naissaar, Tallinn, Tartu, Pärnu.

Author's addresses: ${ }^{1}$ Retired scientist, Mahtra 9-121, 13811 Tallinn, Estonia; ${ }^{2}$ Retired scientist, Rõõmu tee 4-11, 50705 Tartu, Estonia; *e-mail: heldsander@gmail.com

\section{Introduction}

Many modern towns in Europe already existed in the Middle Ages as trading towns, encompassing large urban territories. It could not be otherwise, since an autonomous medieval settlement had to be capable of sustaining and clothing itself. In other words, apart from the built-up area the town had to have enough land for growing food for human and animal consumption as well as for satisfying all other urban needs (Zobel, 2001). One of the most important resources in a town was forests falling within the town precincts, since demand for wood was fairly high. As the towns expanded, the function of the forests changed. The focus shifted to forest plant- ing; various gardens sprang up, green areas were established and trees were planted in yards, around churches, along streets and elsewhere.

There have been multiple studies on conflicts in forestry, the formation, essence and diversity of forests and parks in European cities, but we will highlight two here (Hellström, 1996; Konijnendijk, 1999a, 1999b). According to the latter, conflicts arise (1) more widely due to confrontations between forestry, forest protection and other forms of land use; (2) between different types of forest use and users. For example, there may be conflicts between forest conservation (protection) and recreation, wood use, hunting but also between recreation and hunting; (3) between recre- 
ation types and between them and nature conservation, and between hunting and poaching; (4) between forest policy, planning and consequences of forest management; (5) internal conflicts, organisational conflicts and conflicts between owners. However, it must also be kept in mind that conflicts should not be considered purely negative. If they lead to understanding and cooperation, conflicts can be a force for a positive change, but if they remain unresolved or ignored, they may cumulate and become destructive (Ayling \& Kelly, 1997).

However, the expansion of towns and increase in the urban population were accompanied by a reduction in vacant land, leading to increased pressure on urban forests, later also on green areas. All these factors caused disagreements between citizens and town governments, which sometimes led to several different, minor or major, conflicts. As leisure and wealth grow, human activity in forests becomes very high. Many leisure activities in forests are mutually incompatible and cause conflicts between users. Social sciences and the new science of environmental psychology can be used to explain the real feelings of people towards urban forests and to help with their overall development. The specific requirements for mutually incompatible uses can be met in separate regions by detecting and designing features that both attract and discourage (Hunter, 2001).

This approach is linked more or less to our previous research: Sander \& Randrup (1998), Meikar (1998), Meikar \& Sander (2000), Sander \& Meikar (2000), Sander (2001a, 2001b), Meikar (2002), Sander \& Meikar (2003), Sander et al. (2005), Konijnendijk et al. (2007), Sander \& Meikar (2015), Magnus \& Sander (2019).

\section{Short history of the development of urban forestry in Estonia}

Below we look at what disagreements are known to have surfaced during the devel- opment of Estonian towns beginning from the Middle Ages. The upper time limit we have set here is 1940, when the Republic of Estonia was occupied by the then Soviet Union. Thenceforward, the development of towns took a totally different turn. Another period of social transformations started in 1991 when the Republic of Estonia regained independence. The towns saw a substantial rise in building activity, which fairly often entailed a loss of urban forests and grasslands and a reduction in the number of urban trees as well as the emergence of conflicts between the citizens' desires and the town governments' will. An in-depth study of that period is yet to come.

In general, it may be noted that "green" conflicts stem from different understandings of the relations between the nature and humans, and they usually surface in times of great social metamorphoses.

The most appealing feature of the Estonian tradition has been considered great and deep sensitivity to nature, inspiring devout and devoted reverence for the latter (Loorits, 1990). Hence, Estonians were characterised by a custom of venerating trees. In this regard, mention may be made of a report from the late $16^{\text {th }}$ or early $17^{\text {th }}$ century recorded by the Jesuits who had their own educational establishment in Tartu: "By their ridiculous and superstitious customs the people are said to worship trees, and when they are being cut down they unhesitatingly resist, ready to rather die than surrender." (Helk, 1977: 192) Apparently, that report concerned trees growing in sacred groves. Those groves represented forests where sacrifices were brought. They were held sacred as points of contact between the natural and the supernatural worlds. In Estonia, each community (village, commune, parish), occasionally even a farm, has had its own sacred forest (usually a deciduous grove) or, in an exceptional case, a sacred tree or stone. These were fenced in to protect them from animals, and no trees were felled or branches broken there. 
Since 1219, when Estonia was conquered by foreign invaders for long centuries, the popular perception of nature started to change. It was also reflected in the attitude towards the forest and trees. At the same time, it may be noted that the ancient perception of nature has survived to date in the memory of Estonians; how it is expressed in each particular case is another matter. Unfortunately, the ancient perception of nature failed to transmit to urban nature.

For many peoples, the perception, valuation and preservation of urban nature has been a long process. It began, as always, with the relationship between each country's citizens and towns. With regard to Estonians we have to take into account that towns in Estonia were not founded by the native population but by foreign invaders. Estonians did not embrace the town until as late as in the $19^{\text {th }}$ and particularly in the $20^{\text {th }}$ century. Estonian architecture historian Karin Hallas (1995: 91) has written: "Estonians came to town but that did not mean immediate embracing of the town. The capitalist town with its novel milieu, industrial development, variety, busy life, fragmentariness and stresses effected dramatic changes in the existing norms and customs of community life, giving rise to new social strata and relations, a new culture and new morals. Big towns inspired admiration and desperation, hope and anxiety." The ideology of the Estonian national awakening in the $19^{\text {th }}$ century had inculcated the idea that the countryside is good and the town is bad (Hallas, 1995). It has been emphasised that the development of towns at the turn of the $19^{\text {th }}$ century should be regarded as an international rather than national phenomenon, since industrialisation and urbanisation are essentially international processes (Sutcliffe, 1980).

Primary utilisation of nature in the form of wood started in towns established in the Middle Ages (Tallinn, Haapsalu, Narva, Tartu, Viljandi, etc.), the precincts of which also embraced forests. Already since 1297, forest utilisation was regulated by various protective measures (Sander \& Meikar, 2000) until the promulgation of the respective forest preservation legislation. In one way or another, they also concerned forests in and around towns.

Historically, Estonian urban forests could sometimes have been situated within the precincts of towns. Predominantly, however, they were part of municipal estates. Towns were interested in forests primarily for economic reasons, since forests satisfied the need for wood of municipal estates and their peasants and, if situated in the immediate vicinity of towns, also of urban institutions. An exception in this regard was the oak forest on Kopli Peninsula, which fell within the precincts of the town of Tallinn. By the first half of the $16^{\text {th }}$ century at the latest, the oak forest had become a beloved recreation ground for the townspeople. In the late $19^{\text {th }}$ century, Kloostrimets, just outside Tallinn, began to acquire a similar standing.

More systematic management of urban forests was in some places introduced in the first half of the $19^{\text {th }}$ century but did not become common until the second half of the century. In general, the use of urban forests was moderate; attempts were made to prevent their transformation into farmlands.

Urban greeneries, which were launched in the early $19^{\text {th }}$ century, induced a new perception of nature in the citizens, which initially they were reluctant to embrace. The stress and destructive attitude prevalent in towns was also reflected in the attitude towards urban greeneries.

Quite a few examples can be given to illustrate this. At the end of the $18^{\text {th }}$ or in the beginning of the $19^{\text {th }}$ century the first alleys were established in Tallinn. Trees planted there were poplars. In 1819 the trees of the alleys were quite young, so Toll, the Chief of Police of Tallinn found it necessary to protect them. He wrote that the goats that ran around damaged the trees on the promenade. The owners of the goats should take 
care that it would not happen again and compensate for the damages (Alamaa \& Kivi, 1966).

By 1822, a public garden had been completed in Toompea district, Tallinn, intended as a place of entertainment for the townspeople. On 16 September 1827, however, it appeared that the Toompea garden had been ravaged, benches smashed, trees broken, the terrace trampled and the barrier knocked down (Alamaa \& Kivi, 1966).

In 1894, two peasants residing on Naissaare Island just outside Tallinn, Isaak Lut(h)er and Isaak Rosen, were convicted and fined in the town by a court decision for damaging benches and trees on Telliskopli Avenue. To prevent vandalism, guards were stationed in avenues and parks in the summer. Avenues outside the town were guarded all year round (Tarand, 1984).

The reasons for vandalism varied greatly; undoubtedly, this betrays the attitude towards the town and the town's greeneries.

Next, we will have a closer look at three Estonian towns that have seen the highest number of urban forestry conflicts. The towns are Tallinn, the capital of Estonia, situated on the south coast of the Gulf of Finland; Tartu, situated in central Estonia; and Haapsalu, situated in west Estonia.

\section{The case of Naissaar Island near Tallinn}

The first major conflict over forests owned by towns in Estonia is known to have broken out in Tallinn in the 13th century when Estonia was subject to the kingdom of Denmark. Its cause was the kingdom's increased interest in the forests of Naissaare Island, which was formally owned by the town of Tallinn, resulting from an increased need for wood. It could partly be blamed on the legislation, which bore the marks of the historical legacy (Meikar, 1997; Ratas, 1997; Meikar, 1998; Sander \& Meikar, 1997; Sander \& Meikar, 2000).

On 17 June 1297 King of Denmark Erik Menved VI signed the following document $($ LUB = Bunge, 1853: Nr. DLXVI): Erik, the
King of Danes and subordinated nations by God's grace, the Duke of Estland, wishes everyone reading the present document, salvation by the Lord forever. We ban severely by the grace befallen to us everybody and in any conditions to cut trees or to burn charcoal on our islands Nargheten/Naissaar/, Wulff/Aegna/, Blocekarl and Rughekarl/ now the peninsula Paljasaar, except for our castle and town of Tallinn, as the custom has been from the ancient times, if our condemnation and royal punishment are wished to be avoided. As a testimony of this time we let to add here our stamp, given in Roskilde, anno Domini 1297, on the day of blessed Bocolphus, the alet and witness, in presence of us and honourable father Johannes (Jens), the bishop of Roskilde and the witnesses, Mr. Nicolaus (Niels), called Biker, our castellan Achone Jonesson (Aage Jonsen), our former castellan David Thorstinson (Thorstenson) and Otto von Rosen.

The largest and richest in forests of these islands - Naissaar with the area of $18.6 \mathrm{~km}^{2}$, about $9 \mathrm{~km}$ long and and about 4 $\mathrm{km}$ wide with the highest point $27 \mathrm{~m}$ above sea level, was most influenced by this act. The island situated in the mouth of Tallinn Bay, at ca $8 \mathrm{~km}$ from the capital of Estonia. The island is covered with forests. Only a narrow coastal belt is open and left under the direct influence of waves (Punning et al., 1998).

Up to the year 1346 Tallinn belonged to Denmark as the capital of the duchy. After the legal act by Erik VI Menved from 1297 and the reconciliation of the arguments with St. Michael's Cistercian nunnery, which, in 1343 and 1368, acknowledged the rights of the town to the islands, Tallinn could consider the forests of the nearby islands as the town's property (LUB = Bunge 1955, 1957). Although these were the common domain of the castle and the town, the latter became the actual manager of the islands.

The extant scarce records indicate that Tallinn's handling of island forests, particularly those on Naissaar and Aegna, in 
every way evidenced good stewardship as measured by modern standards. Selective cutting was employed, though apparently to a modest degree - at least there are no records of any major forest clearing. Forest use on the islands was under the effective control of the Town Council and strictly regulated. The situation changed in the $17^{\text {th }}$ century, however.

In the $17^{\text {th }}$ century, a sharp conflict developed between the City of Tallinn and the Governor representing the Swedish power, over the use and even the ownership of the forest of island Naissaar. It started with an argument about the borders of the town's mark, while the special interest of the State in this island became gradually more evident. The base of this argument was the ambiguous regulation from the year 1297, which determined the common use of the islands by the town and the castle. While it did not create problems earlier, it meant a conflict with the central power in new circumstances. So, the Governor of Estonia asked for documentary evidence of Naissaar belonging to the town from the Town Council in 1642. In 1643 the state land surveyor $\mathrm{D}$. Reimers tried even to dispute the right of the City of Tallinn to Naissaar. To settle the matter, a special committee was formed, but this was also unable to offer any solution.

The Governor of Estonia took advantage of the situation and procured 500 beams, 5,000 fence planks and 100 cords of firewood from Naissaar, without informing the town, which later added to the resentment by the town. Subsequently, the Queen Kristina of Sweden had to interfere. In the royal resolution of Nov. 23, 1653 she firmly opposed the trespassing on the forests of the islands, and stood by the town in their protection (Nottbeck, 1884).

The administration of the Government also began to take advantage of its rights on the joint property, first of all felling timber for fortifications. Naturally, this aroused protests and counteractions in the Town Council, which tried to regulate the forest use on Naissaar, this way or the other. It is known that in 1686, a special guard was sent to Naissaar whose task was to monitor that the felling for the Town Council would not exceed limits. The forest was devastated also by outsiders. In the aforementioned year the Town Council complained to the Governor General of Livonia that the Governor of Estonia allowed lumbermen on the island without consulting the town. Something unexpected appeared - a peasant from Viimsi, caught in the act of felling, presented a permission to cut 100 beams, bearing the signature of the Governor of Estonia. The Town Council sent a protest to the Governor's residence on Toompea, calling attention to the town's right to make decisions regarding Naissaar. A sentence in the protest describes the attitude of Tallinn towards Naissaar: "...the island has been picked out for all sorts of useless clear-cutting, which stands beside the town like a sanctum and treasure". The Town Council also emphasized that only exceptional felling was allowed there for the town's fortifications and Toompea, but for the latter, the Town Council was to give special consent every time (Meikar, 1997; Sander \& Meikar, 1997).

A solution unfavourable to Tallinn was reached in 1689 - in connection with the reduction of the estates, nearly all the town's mark including the islands was nationalized to the Swedish state. While the town could use other parts of its possessions, the islands were taken under direct state management. This meant that the town was denied any economic activities there, including felling.

The capitulation agreement of 1710 of Tallinn to Russia promised to restore the former landed property, as unlawfully expropriated, to the town. With the Uusikaupunki peace treaty in 1721 the Town Council got the possibility of directly appealing to the Czar of Russia Peter the Great in connection with the promises made about the marine islands. The committee for restitution which worked in the years 1725-1728, 
restored the islands of Paljassaare, but on April 4, 1728 passed the negative resolution about Naissaar and Aegna, which was ratified by the Senate (Supreme Court) on October 15, 1742 (Nottbeck, 1884; Pullat, 1976). The reason given was the same resolution of joint usage from 1297. Concerning Naissaar, it was observed that the town has not been able to prove its right on the island and, as if in reward, was given the permission to use the forest for the com- munal needs of the port and the town). At least the latter promise was never fulfilled, if we do not consider the few proffers from the beginning of the $19^{\text {th }}$ century, of the possibility of clearing the windfall on the island for fuel wood (Figure 1).

Thus, the first conflict over urban forests in Estonia was occasioned by the ambiguity of the then legislation and the fact that the state power, though initially unwilling to meddle in the town's affairs, later

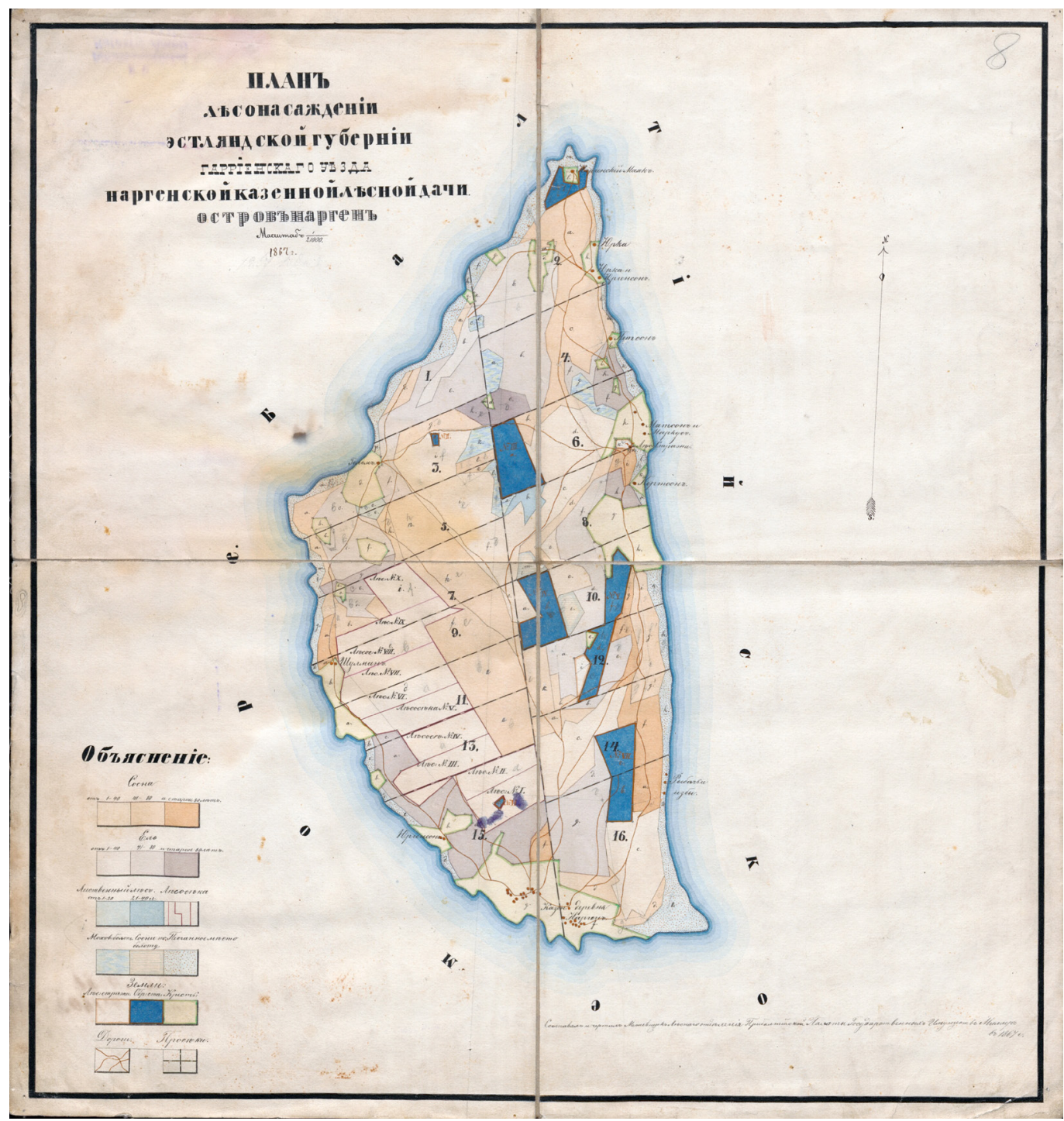

Figure 1. 1867 forest plan of the island of Naissaar.

Joonis 1. Naissaare metsade plaan 1867. 
developed a desire in connection with the development of the state to assert itself on opportune occasions. And the town proved to be the losing party in the conflict.

\section{Conflicts over urban forestry, the fortification works and Northern War in Tallinn}

In modern sense, the town of Tallinn was founded in 1219. The town was granted Lubeck Town Rights in 1248 (Kala, 1998). The development of Tallinn has been considerably impacted by the fact that it has for long centuries been a town of fortifications. This has brought both negative and positive consequences to the town.

The establishment of fortifications has often inflicted heavy losses also on the townspeople. In anticipation or fear of military invasions, suburbs were destroyed, which led to discords between the inhabitants, the town government and the commander-in-chief of the troops stationed in the town.

The first report of this sort dates from the $16^{\text {th }}$ century. The fortification works and sieges of Tallinn during the Livonian War resulted in the destruction of Roosiaed [Rose Garden] dating from the $14^{\text {th }}$ century and owned by a guild of Tallinn - Suurgild [Great Guild] (Pabst, 1873). The chronicler Balthasar Russow (The Chronicle, 1988: 153-154) writes: "This Rose Garden was situated opposite the Great Sea Gate, quite close to the large city tower. During the good years of peace, the merchants had added soil to this site and elevated it, making it into a raised park with a splendid prospect onto the sea and other nearby spots. It was completely enclosed by a wall so that no swine or other livestock could come up onto it. And in the middle of the park there stood a tall and beautiful green tree, with long and spreading branches, and under the tree a number of benches had been placed. ...... during the second Muscovite siege, this splendid pleasure garden was dug up and became a garden of sorrows, when the people of Reval turned it into a redoubt with moat and palisade opposite the large tower at the Great Sea Gate."
Notoriously known was the destruction of the gardens behind the town wall in the second half of the $17^{\text {th }}$ century when the establishment of earthen fortifications - bastions - started. It has been noted that the citizens missed very much the flourishing gardens now destroyed, with their fruit trees, berry bushes and flowers, small summer cottages and arbours (Kenkmaa \& Vilbaste, 1965).

On the outbreak of the Northern War demolition of houses closer to the fortification zone than $320 \mathrm{~m}$, destruction of gardens and felling of large trees was ordered in the suburbs of Tallinn, which then was under the Swedish rule (Kenkmaa \& Vilbaste, 1965; Pullat, 1976). When on 22 August 1710 the Russian forces under General Bauer captured the approaches to Tallinn, the then Tallinn military commander, Vice Governor Dietrich Patkul, issued the command to burn part of the town's buildings. This also involved burning many gardens and large trees and even, according to one report, destroying a church in the town Kaarli Church. The beautiful large trees surrounding the church were either burnt or felled (Pilliroog, 1997). Under the 1721 Uusikaupunki Peace Treaty Tallinn was annexed to Russia, surviving, however, as a town of fortifications.

Another case in Tallinn, similar to the one above, is known from the period of the Crimean war in the $19^{\text {th }}$ century (18531856). In fear of the landing of troops from the English and French warships cruising around the Gulf of Finland part of Kalamaja District was demolished in March 1854. This included the pulling down of dwellings and outbuildings, destruction of gardens and felling of large trees and part of the trees lining the town's northern boulevard. The command was issued by the then commander-in-chief, General Friedrich Wilhelm Rembert Berg; however, even the Governor of Estonia, Johann Christoph Engelbrecht von Grünewaldt, could not grasp the strategic importance of the undertaking. 
All these actions engendered much resentment among the citizens. They were remembered decades later and, additionally, recorded in historical sources and publications.

\section{The case of Kloostrimets forest (Klosterwald) in Tallinn}

It must be understood that progressive ideas on forestry did not come easy but always through hardships, occasionally causing divisions within town governments themselves. An example of that can be given from the Pirita district, East Tallinn, from the second half of the $19^{\text {th }}$ century (Meikar \& Sander, 2000, 2001).

Not far from the mouth of the Pirita River stands Kloostrimets [Convent Forest], which first belonged to Pirita Convent established in 1400 and destroyed in 1577, and later was passed on to Nehatu Manor. The town purchased Nehatu Manor in 1733 and thus also acquired Kloostrimets.

In 1866, the first forest survey was performed in Kloostrimets by Wilhelm Kühnert (1864-1883), the town's Chief Forester. According to him, the forest had 180 ha of dune pine stands and 216 ha of deciduous stands and inferior coppices. In 1875 a forest plantation was launched in Kloostrimets. By 1904, ninety-four hectares of plantations had been established, of them 28 ha on an area formerly covered by birch. The future plans envisaged forestation of 65 ha of clearings and sparsely stocked areas, and conversion of 76 ha of birch stands into pine stands.

The new Chief Forester (1883-1904) Adolph Müller desired to develop the management of the town's forests along traditional lines; however, totally different ideas, which were novel for their time, had gained currency in the Town Government. These did not rely on purely economic considerations but on the understanding that suburban forests need to fulfil the recreational function, to the overshadowing of the timber production function. In 1893, A. Müller performed a new forest survey in Kloostri- mets. In the same year, the Chief Forester initiated the logging of over-mature pines. This triggered a wave of vigorous protests in the press, as a result of which the Town Government abolished such loggings. According to the emotional judgement of the Chief Forester, this amounted to economic thoughtlessness, since the valuable forest was abandoned to its fate.

At that time, clear-cuttings were employed in Kloostrimets, although on very small areas. They were combined with sanitary and tending felling, if necessary. A. Müller's management plan for Kloostrimets forests dated 1903 foresaw considerable intensification of forest utilisation, under which the annual yield area was to be expanded to 2.9 ha. The Town Government, however, did not approve the plan, at least initially. Not surprisingly, this embittered the Chief Forester. In 1904, A. Müller presented to the Town Government a report on the condition of the urban forests and the prospects for increasing forest income, in which he set out the controversies that had emerged. Apparently, it was the different visions of the management of the forests that led to the resignation of Chief Forester A. Müller in 1904 (Sander \& Meikar, 1996; Meikar \& Sander, 2000).

\section{The case of Falkpark in Tallinn}

Tallinn, the capital of the Republic of Estonia, was granted the rights of a town in the $13^{\text {th }}$ century. Administratively, the town's territory was divided into two parts - Toompea [Cathedral Hill] and All-Linn [Downtown]. Toompea was the seat of the state government and its administrative jurisdiction also extended over some suburbs of All-Linn. All-Linn, in turn, was ruled by Tallinn Town Government, which managed all the affairs of the town.

From the very birth of Tallinn, great emphasis was laid on its fortification. A high town wall was built and extensive earthen defences were established in the form of bastions. For the main part, the zone of fortifications was completed by the 
early $18^{\text {th }}$ century. Following the Northern War, when Tallinn was annexed to the Russian Empire under the 1721 peace treaty, relatively few improvements were made on the fortifications.

In the early $19^{\text {th }}$ century people in Tallinn started to realise the need for public green areas. This was facilitated by the demilitarisation of the town's fortifications which begun in 1820. Already in 1821, the first section of the zone of fortifications was turned over to the Town Council. It was decided that the first area to be put to use should be the one in front of the Harju Gate on the southern side of the Old Town. The Town Government had no clear idea concerning the future of the area; they considered selling it, renting it or leaving it in the town's ownership. The last view gained the upper hand, and in 1822 the Town Council announced that the area to be released in front of the Harju Gate would according to the people's request remain with the town and be turned into a public garden after the wall was levelled. The funds required for establishing the garden were collected from private persons. The park, which became known under the name Lasteaed [Kindergarten] (in German, Kinder Garten), had a place for children to play and enjoy fresh air. It was completed in 1823 on an area of approximately 1.3 ha. At the same time, Lossipark [Palace Park] and the so-called Komandandi Aed [Commandant's Garden] were founded on Toompea, which were not intended to be eclipsed by All-Linn. The first mentioned area was given into public use (Kenkmaa \& Vilbaste, 1965; Sander, 2001a).

Another attempt to found a public park in the town was made in 1849 by Grünewaldt, the Civil Governor of Estonia. It was planned to be established on a suburb of Toompea. Grünewaldt asked the Military Governor of Riga to seek permission for it from the Engineering Department in St. Petersburg, notifying that in preparation for the park he had even had the ground by the so-called Värvalitiik, that is, Dyer's Pond, levelled. However, permission was not granted since the site in question was located in the esplanade area in front of the fortress (Alamaa \& Kivi, 1966). It is known that in the early $19^{\text {th }}$ century it was an open sandy area surrounding a pond, which was called "Färber Teich" [Dyer's Pond] in German, after a dyehouse standing nearby, across the street.

This sandy field was purchased in the early 1850s by Hans Heinrich Falck (17911874), alderman of a guild of handicraftsmen composed of Estonians (Toomgild [Castle Hill Guild]) (Falck, 1914; Kenkmaa \& Vilbaste, 1965; Sander, 2001a; Sander \& Meikar, 2015). H. H. Falck started to establish a park on the 1.6-ha plot. According to a map of Tallinn from 1856, the park was basically completed by that time; the map shows meandering paths lined with trees. Also preserved was the local pond. The completion of the park by that time is also confirmed by the fact that one of the local oaks was probably 155 years old in 1999. On one side of the park H. H. Falck built a music pavilion and a restaurant, which in its time was eagerly frequented by the Tallinners (Kenkmaa \& Vilbaste, 1965; Sander \& Meikar, 2015). By 1864, the pond in the park had been filled up and more trees and bushes had been planted.

In 1860, "Revalsche Zeitung" (No. 3) published an article reading as follows (Tarand, 1975: 594): "On one Sunday in July an orchestra was playing the whole day in Falkpark, and there were plenty of people present in the park. We can only wish progress and flourishing to the new entertainment and promenading area so that it would ever afford recreation and refreshment to the inhabitants of the Toompea suburb, the very citizens that stay in town in summertime."

By the contract of gift of 1 May $1868 \mathrm{H}$. $\mathrm{H}$. Falck donated his garden and buildings to Toomgild (Sander \& Meikar, 2015). Under the contract, it was to be opened to the public and become a park in common use. Toomgild, however, did not fulfil the condition. 
After the enforcement of the 1870 urban law in Russia the town authority was to be composed of the town council and the town government. On 26 March 1877, the office of mayor was also instated. A major change was termination of the administrative division of Tallinn into two. In 1889, Toompea was eventually united with AllLinn (Pullat, 1969). Consideration must also be given to the fact that the elimination of the administrative halving resulted in part of Toompea and its suburbs being turned over to the Town Government while the remaining part was left with Toomgild.

In the summers of 1882-1887, Toompark was leased out to the society "Lootus" ["Hope"] made up of Estonians. The society organised summer festivals there. One of the grandest and most memorable ones was the Harju County Choir Song Festival held in June 1887. It was participated by 13 choirs and two orchestras. Entrance to the park was free. Indeed, local inhabitants were less than enamoured with the garden, particularly because of the great noise coming from the park (Vende, 1990). In those years new trees were planted in the park, which is evidenced by the age of the larches found there.

In the early $20^{\text {th }}$ century, some members of the Town Government (apparently Estonians) desired to convert the park into a public green area (Sander, 2001a). On 16 May 1904 the Town Government received a long letter from Delegate Jaan Umbleja, in which the latter demonstrated the need of the neighbourhood residents for a park, referred to H. H. Falck's deed of gift and desired that the park be always open to the public and made fit for such use. On June 1904 the Town Government decided to turn the garden into a public park. This did not succeed, however, as Toom Park tenants lodged a complaint against the Town Government. The town's desire to give the park into common use, which was at variance with Toomgild's intentions, was countered at Tallinn District Court on 21
May 1911, where the lawsuit was won by the Town Government.

The tenants appealed in St. Petersburg, the capital of Russia, where the case dragged because it was unclear who the official owner of the land under the park was. It appears from a letter written by the Town Jurist of Tallinn that according to the summary of the orders of the Supreme Provincial Court of Estonia of May 7 and 8, 1868 Toomgild was registered as the owner of the house built in a public place but not of the land itself.

On 24 February 1918, the Republic of Estonia was formed, and the fortunes of Falkpark took a new turn. On 7 June 1918 Toomgild leased it to Jaan Alksnis until 1 July 1927. J. Alksnis in turn leased the park and the buildings to Bernhard Leer on 23 July 1920, who then leased it to the Forest Industry and Trade Cooperative (FITC) "Arbor" on 7 February 1921. J. Alksnis and B. Leer both lived at 1 Falkpark Road, of which "Arbor" was also one of the tenants. Therefore, there might have been some collusion here for permanent acquisition of the site.

On 26 July 1919, Falkpark, excluding the buildings, was expropriated by the Republic of Estonia and given under the administration of the Public Education Division.

In connection with the dissolution of Toomgild and the assignment of its property to the jurisdiction of the then Ministry of Work and Welfare on 16 June 1921 the Supreme Court ruled Falkpark to be a property of the Republic of Estonia; as well, it was noted that the park had never been in the town's ownership.

On 18 May 1922, the Ministry was proposed to put Falkpark at the disposal of the Tallinn Construction Division. At the same time, the Construction Division prepared plans for reconditioning the park. The first reconditioning works were performed in 1922 and the trees in bad condition were felled. As the lease of the park had not expired and the tenant did not want to relin- 
quish the plot, the FITC lodged a complaint against the Town Government. The complaint proved fruitless. The Town Government's desire to put the part to public use was also supported by the petitions of several organisations and residents of the neighbourhood.

After the expiry of the lease to the FITC "Arbor", Falkpark was leased to the athletic association "Sport", which held it until 1 April 1929. The association agreed to establish a park for children provided they themselves could lease the buildings on the plot for six years). The agreement was reached indeed, and on 10 July 1929 work was started on the reconditioning of Falkpark. Children's playgrounds started to be established in the so far relatively disordered park, which was completely reconditioned in the subsequent years. Thus, the citizens' desire to freely visit the park was finally fulfilled following more than 55 years from $H$. H. Falck's death. Falkpark has since been in common use until today.

\section{The case of Lossiaed (Palace garden) in Haapsalu}

The most muddling case in Estonia in juridical terms was the conflict resulting from a plan to parcel out Lossipark [Palace Park] (in German, Schloßgarten) in Haapsalu (Meikar, 2002; Sander, 2001b).

The town of Haapsalu, which conventionally is considered to be founded in 1279 , is situated in west Estonia, by the seaside.

Haapsalu's Lossipark embraced a territory marked out in the $17^{\text {th }}$ century, which became known as Linnuseaed [Citadel Garden]. On one side, it bordered on the local $13^{\text {th }}$-century Bishop's Citadel, and on the other on a regularly patterned park planted around a stately mansion built in 1830 by Count Karl Magnus De la Gardie (1788-1856).

In 1899 the premises were acquired by Count Nikolai Georg Engelbrecht von Brevern De la Gardie (1856-1929). The maps and the 1900 record of realties of the town showed the total area (10.3 ha) and the boundaries of the premises; also known was the area of the municipal land (2.1 ha), but not its boundaries. The premises were actually composed of two real estates having different legal status but registered as one entity in the Register of Real Estate. As such, the entire premises were regarded as the property of the Count, who was taking care of it. Whether it was in full municipal ownership, co-owned by several landholders under a combination of different forms of ownership or even in private ownership did not really matter in practical terms until the issue of parcelling out and selling of Lossiaed [Palace Garden] came to the fore.

On 23 and 24 February 1922 von Brevern De la Gardie who had gone to live in Italy, had his attorney notify the Haapsalu Town Government of his intent to parcel out and sell the premises. The Town Government indeed decided that the tract, which was lying idle at that time, blemished the town's beauty and was required for raising the dwelling density and expanding the town. On 10 March 1922 the town's Construction and Appraisal Committee granted the Count permission to parcel out the premises. The permission was approved by the Town Council on 17 March, with 19 councillors voting for and 5 against.

The Town Council resolution unleashed a lively discussion among the citizens and prompted opposition to the Town Government's decision. As the issue in question was of vital importance to Haapsalu's development the mayor convened a meeting of the town councillors and representatives of the local societies on 12 April. At the tumultuous assembly, the following proposals were put forward: to purchase the Palace Garden, to lease it from N. von Breven De la Gardie, to hold a plebiscite to get the citizens' view and to agree with the parcelling out and sale of the Garden. By 15 votes in favour (and with 20 abstainers) it was decided to begin negotiations with the Count to obtain a long-term lease on the premises. 
After long debates, the Town Council meeting of 28 April rejected the idea of either purchasing or leasing the park. Instead, the Count was proposed to donate the premises to the town. The proposal was turned down, however. Next came the intervention of the Government of the Republic of Estonia, which at an informal meeting considered purchasing the premises to the state or granting a loan to the town of Haapsalu for the latter to buy it into municipal ownership. Neither view was considered feasible, however.
According to N. von Breven De La Gardie's plans, 6.3 ha of land were to be parcelled out (Figure 2). For the main part, they embraced the park surrounding his mansion, bypassing the part of Lossiaed still existing today. The plans were presented to the pertinent division of the Ministry of Internal Affairs. There, however, they were rejected without any warning on 28 October on the grounds that "by building up a major park area the town of Haapsalu would forfeit the opportunity to develop public gardens inside the town". Although

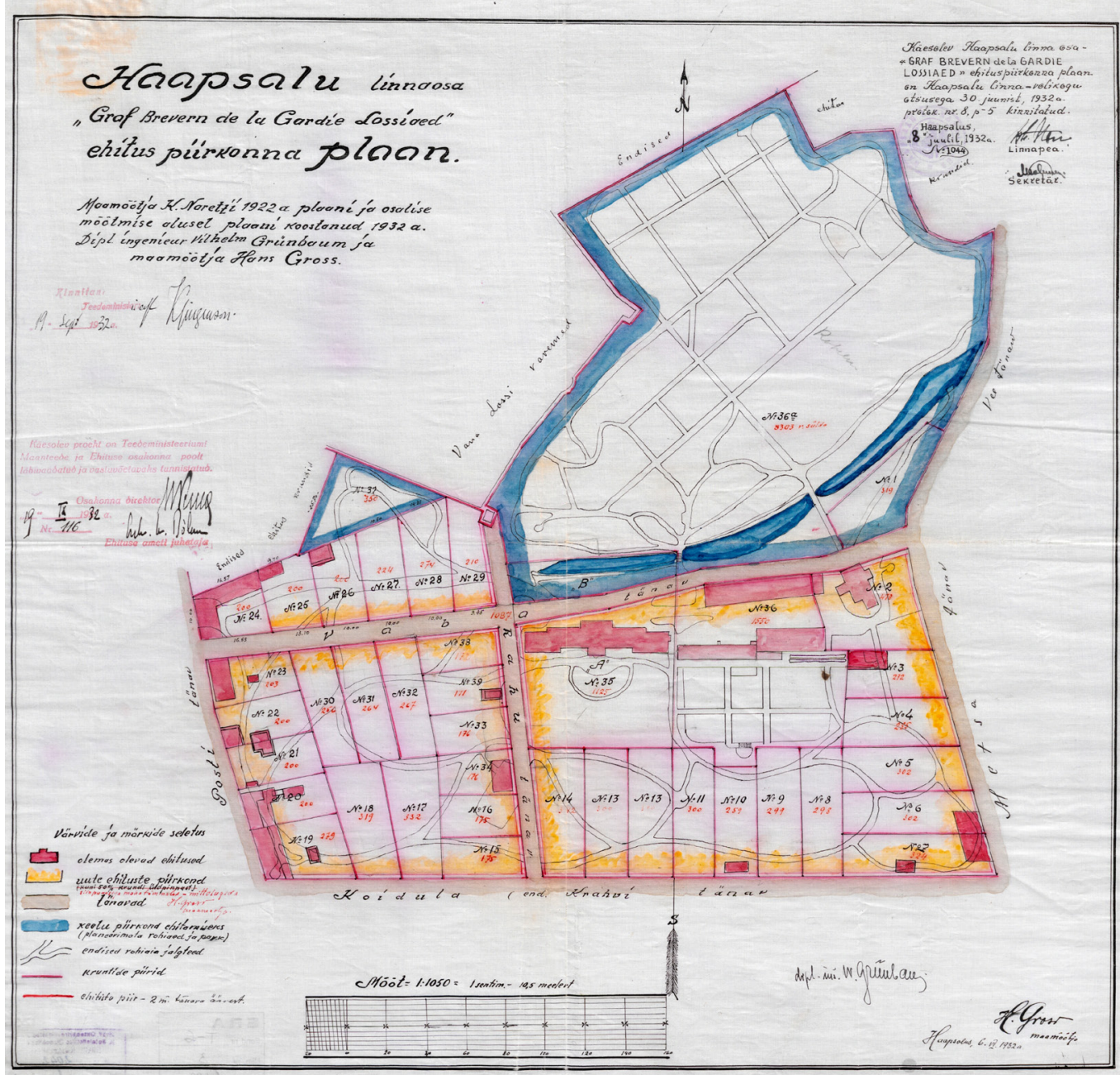

Figure 2. Count Breven De La Gardie's construction area plan from 1922/1932.

Joonis 2. Krahv Breven De La Gardie ehituspiirkonna plaan 1922/1932. 
the Town Government decided that the ban on parcelling would hinder the town's natural development the Town Council on December 8, 1922 annulled its permission to parcel out and sell the premises given on 17 March of the same year.

Considering the confused form of ownership of the premises the Count prepared a new parcelling plan early in 1923. The plan was approved on 15 March 1923 at the Republic of Estonia Ministry of Transport. Accordingly, the Haapsalu Town Council had to abrogate on 27 March 1923 its resolution of 8 December 1922. It was stated that due to financial considerations the town of Haapsalu abandons its pre-emptive right of purchase. The first plots were sold by the Town Government's permission in 1924, with some councillors being among the purchasers.

Thus, the conflict had essentially found a solution by the spring of 1923 . The parties reached an oral agreement in that the smaller tract was acknowledged as belonging to the town and the Count abandoned any claims on it. A problem arose when the Town Government, assisted by an attorney-at-law, delved into the documents and discovered the potential for different interpretations. It appeared that $\mathrm{N}$. von Breven De La Gardie's ownership rights might altogether be disputed and the entire premises regarded as land belonging to the town. Naturally, it was known that Lossiaed cannot be in full ownership of the town; however, the unexpected discovery in the documents of the potential for different readings opened up a tempting and, if successful, lucrative opportunity for legal manoeuvring. When on 30 June 1923 the Count's attorney, leaning on the oral agreement, sought the Town Council's recognition of two forms of ownership, which would then have provided the basis for amending the records of the Register of Real Estate, it was not granted. On $14 \mathrm{Au}-$ gust of the same year, the Haapsalu Town Council found that the premises may not be in dual ownership, and if they were the
Count himself should identify the forms of ownership and the boundaries. N. von Breven De La Gardie's proposal was declined; as well, he was denied the town's assistance in resolving the legal aspect of the case. A special committee formed by a resolution of the Town Council had already drawn a definite conclusion that the 1900 record of the town's realties permits regarding the premises as municipal land. These Council resolutions created a legal conflict, and as either party gave their own interpretation of the historical documents, a case was made for the ensuing series of lawsuits.

The litigation took place in 1924-1925, and sentences were given in favour of either party. The proceedings were terminated on 25 February 1926 by the Republic of Estonia Supreme Court, which ruled that the town was entitled to no more than the municipal land defined. It was emphasised that the erstwhile error by which private and municipal lands were entered in the Register of Real Estate under a single number did not mean forfeiture of the rights of one party in favour of the other but gave ground for acknowledging the rights of both parties and amending the Register entry. Similarly, it could not be inferred from an erstwhile slight expansion of municipal land at the expense of private land that it had been applied to the entire premises. The court ruled that the town failed to produce any documents to verify the claim that it had more land than 2.1 ha.

The homogeneous park surrounding the mansion of N.G.E. von Brevern De La Gardie was indeed sold in plots. The felling of age-venerated trees then ensued, leading to the destruction of most of the park. The parcelling out, sale and build-up was a fairly long process. The last part of the park was built up as late as in 1975 .

The erstwhile species composition of the trees and bushes growing in Lossiaed remains unclear since the respective descriptions have never been written or found. Similarly, the lawsuits of the 1920s 
do not contain a single word describing the park. Initially, the Town Government and the Town Council underscored the importance to the spa town of the green area; later, however, they only occupied themselves with legal issues. The long period of litigation, the tangle of legal issues and the resultant neglect of the premises also diluted the citizens' interest in the case. Although the older part of Lossiaed, which today is known by the name of Krahviaed [Count's Garden], escaped the parcelling-out and build-up, it has lost its distinctiveness accumulated during its long history. The park's present dendrological value is low. It represents an ordinary park community typical of Estonian towns, which is dominated by the autochthonous Norway maple (Acer platanoides L.) and European ash (Fraxinus excelsior L.). Most of the trees have been planted after 1950, some have sprouted spontaneously. Only a few trees are old enough to date back to the $19^{\text {th }}$ century (Sander, 2001b).

Of course, the essence of the conflict was more sophisticated than as presented here. It was not only between the owner and the town but also between different concepts of the town's development, self-interests, etc. We have to understand that in 1918 the Estonian people emerged as an independent nation, which also entailed the burgeoning of urban bourgeois, the surfacing of those interested in making easy money and the development of different interest groups. Quite probably, some were seeking sheer self-gain from purchasing the plots with the purpose of reselling them at a profit in the future.

It must also be noted that the progress of Estonians living in towns (urban Estonians), who were better off economically, was based on the purchase and construction of houses. Through house ownership came political power (Hallas, 1995).

\section{Cases that did not lead to conflicts}

\section{City of Tallinn}

All that was done, as on Kopli Peninsula in Tallinn before World War I, was in compliance with the legal procedure and with the approval of the town governments, which proceeded from urban development considerations and, ultimately, from economic interests. There are no reports from that period of any major display of citizens' dissatisfaction with the destruction of such suburban forests.

The wider range of these instances was the felling of forest on Kopli Peninsula to develop the area into shipyards and workers' dwellings (Meikar \& Sander, 2000; Sander \& Meikar, 1996, 2000, 2003).

For its diverse terrain, variegated oak groves and beautiful coast the Kopli peninsula in the northwest of Tallinn was considered one of the most picturesque places in and around the city. In history, it was known by the names Linnakoppel [Town Paddock; in German Stadtkoppel] or Telliskoppel [Brick Paddock; in German Ziegelkoppel]. The first name can be traced to the fact that Kopli Peninsula was once used for livestock grazing, and the other to a brickyard founded there in the $14^{\text {th }}$ century (Nottbeck, 1884).

The precincts of an institution called Tallinna Linna Telliskoppel [Brick Paddock of the Town of Tallinn] encompassing the northern part of Kopli Peninsula and two small islands (in 1820, its size was $5.25 \mathrm{~km}^{2}$ ) accommodated pasturelands, coppices and deciduous forests. It was separated from the rest of the town by a fence of limestone, granite and pickets. Of great importance among the forests of Kopli Peninsula were oak stands, well-known already in the Middle Ages and protected by some usage restrictions. The first act of law regulating forest utilisation in Kopli was adopted in 1415 when fishermen stopping over there in the fishing season were barred from using the forest. Later, the act was elaborated to bar illegal logging by the 
citizens. At the same time, the town was free to utilize the Kopli forest for its own purposes.

The usage restrictions imposed on the Kopli forest first and foremost served the interests of the town as the preferential user who obtained from here timber required for running and defending the town, namely building port facilities, fortifications, waterworks, etc. Even so, these pragmatic restrictions also contributed to the preservation of the Kopli forest while inculcating a considerate and caring attitude toward Kopli's environment in the citizens. As it was, Kopli Peninsula had become fairly well-known to the latter for its picturesque scenery and oak stands.

Hence, the resentment over the fact that Kopli oak stands were ravaged during the Livonian war by Russian troops in their repeated sieges of Tallinn. This appears from the records of the chronicler $\mathrm{B}$. Russow, according to whom 16 October 1570 saw the approach to Tallinn of large contingents of Russian troops who "They made camp at Teghel [Telliskoppel] near Reval and falled and destroyed the magnificient forest there. At the same time the people of Reval burned and levelled the Fishers' Village where more than two hundred dwellings stood" (The Chronicle, 1988: 135).

The soldiers' ravages, however, did not prevent the town from continuing to use the forest. Large-scale oak cuttings are known to have been performed in 1600 and 1611; in the last-mentioned year, four wagonloads of oak timber were drawn to town from here. Nevertheless, there are no reports of any destructive cuttings of the local forests.

In the late $16^{\text {th }}$ century, the town government leased out the Telliskoppel premises. The lessees were required to observe the restrictions on forest use and, as a novelty, to plant trees. Hence, the first documented reference to statutory forest planting within the precincts of Tallinn concerns the very 1611 act on Kopli. Lessee Hans Dehn was required to facilitate reforestation on his smallholding and plant 200 young oaks there. A lease contract from 1633 obligated two tenants to plant as many as 600 oaks into the Kopli forest.

The $17^{\text {th }}$ century was a time when citizens started to build summer manors and enjoy and appreciate the beauty of the scenery surrounding the town. Thus, Kopli became the citizens' outing area.

In a poem from 1651 dedicated to the place, diplomat and poet Paul Fleming (1609-1640), who for some time lived in Tallinn, called Kopli "Nature's joygrounds" (Du Lustplats der Natur) (Fleming, 1651; Kirchner, 1855; Berger, 1988). Hans Moritz Ayrmanns, a Swedish military man of German descent, who visited Estonia in 16661670, mentions that just outside Tallinn there is a beautiful "forest of joy" (Schönes Lustwältgen) called Great Kopli where one can go for a walk, a horse ride or a cart ride and enjoy every kind of social entertainment (Schreinert, 1937).

In the post-Northern War years, when Tallinn became part of Russia, the town's government was unable to prevent illegal logging by the military in Kopli. For that reason, the Town Council transferred the district to the charge of the town's Chief Commandant Vassili Zotov. Later, Kopli was again put at the disposal of the town, which leased it out. There are reports already from 1733 that the lessees were required to plant at least 50 young oaks. Accompanied was an allowance that if oaks were unavailable, they may plant limes, birches, alders and rowans. Unauthorised cutting of trees in the Kopli forest was forbidden as attempts were made to preserve it as a protected forest. The last-mentioned requirement was made by the Town Council in 1738. Accordingly, Kopli Peninsula was a district enjoying constant attention from the town authorities.

The 1759 documents of the Town Council reveal that the aldermen inspected the fence surrounding the local forest area (erected to prevent livestock intrusion into forest territory). They learned that lessee 
Dietrich Adolph Schröder had been much more diligent than his predecessors in repairing the fence and thus the livestock were kept away from the forest. True, the lessee had done some logging, but that was also acknowledged as silviculturally essential, as an overly dense forest would have been a disadvantage to the growth of young trees. The above testifies to the town's interest in preserving the Kopli forest at any rate and even increasing its area.

Hence the view recorded in the minutes of the Town Council meeting of 2 January 1748 that Kopli should be considered the town's jewel and treasure ("allewege alls eine Zierde und Kleinod dieser Stadt regardiert worden"). At any rate, attempts were made to preserve the Kopli forest and even increase its area and restrict its use.

In 1770 a road to Kopli with better access was built, and in 1774 the graveyards of Tallinn's St. Olaf's and St. Nicholas's churches, along with dwellings for the graveyard keeper and gravediggers, were established in the Kopli oak grove.

In the second half of the $18^{\text {th }}$ century the Kopli forest became fairly popular with the town-dwellers as a resting place. However, some people were out there to spoil the idyll. To protect the peace of citizens promenading in Kopli the police had to intervene on a regular basis. Therefore, several notifications and prohibitions were issued in $1797,1812,1818$ and 1826 concerning the firing of guns, smoking of tobacco, the taking along of dogs and other ways of conduct disturbing the promenaders.

In the mid-19th century, a so-called high forest with deciduous trees grew on the Kopli peninsula, which was dominated by very old, apparently even dying, black alders. Apart from them, the forest accommodated impressive birches, ashes, rowans, elms, limes, and "colossal" oaks (Russow, 1862).

In 1866, the then Chief Forester of Tallinn, Wilhelm Kühnert, prepared a forestry activities plan on the Kopli peninsula. The plan's implementation was started as the resources permitted. In 1880, forest plantations were launched; later, a preserve fenced with barbed wire was established to protect young stands.

The year 1884 may be considered the beginning of more intensive establishment of forest plantations. That year 3,000 pines, 1,000 spruces and 200 larches were planted on the area fenced off a few years ago. Apart from coniferous trees, oaks, birches and other deciduous trees were later planted here.

In 1904, the size of the Kopli forest was estimated at 87 ha. In the first years of the $20^{\text {th }}$ century plantation efforts were continued, eventually expanding the area of the forest to $104 \mathrm{ha}$. All the stock required for planting was obtained from the nursery established here at the very outset.

The Telliskoppel farm belonged to the town of Tallinn until 1912. That year, large tracts of land were sold or leased here for building shipyards and a naval port. The town kept a mere 33 ha of the 104-ha forest, and even that was criss-crossed with a network of roads. This signalled the rise of Kopli as an industrial area, which was deemed highly profitable for the town from a purely economic perspective. Brisk building activity began, including the establishment of infrastructure. The number of jobs in the town grew, the town's revenue increased, etc. Mention must also be made of a lumpsum payment to the town of more than one million Czarist Russia roubles, which was subsequently supplemented by the annual rent.

Owing to the resultant situation Kopli forfeited its silvicultural and recreational functions and accordingly also the Town Government's interest. It is remarkable that in the bulky publication concerning the Town Government's five-year activities issued in 1916 Kopli is never once mentioned as a district of any silvicultural interest.

Not completely, however. In 1916, the Estonian Forest Protection Committee put the size of the Kopli forest at approximate- 


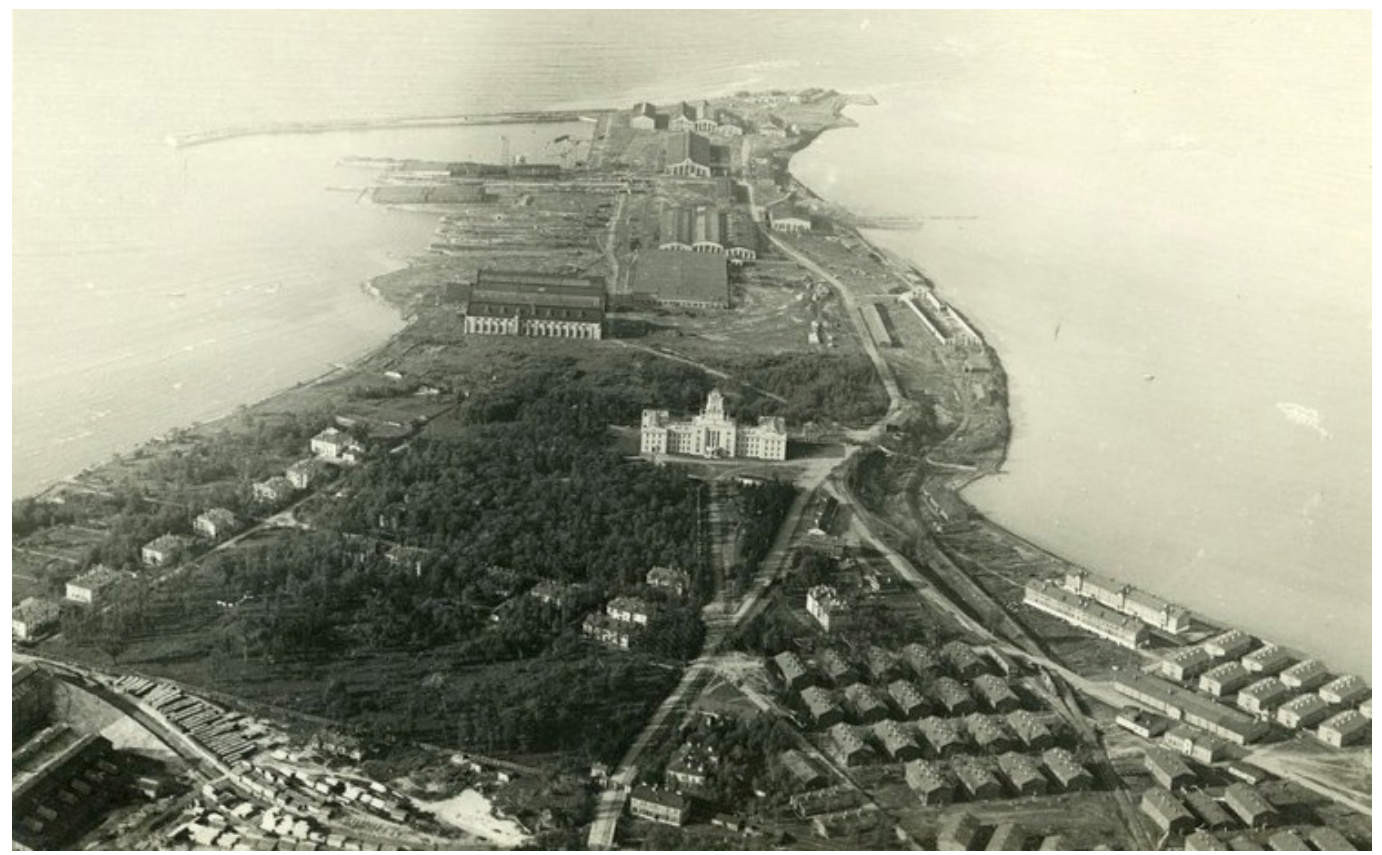

Figure 3. Preserved forests on Kopli peninsula in 1926.

Joonis 3. Kopli poolsaar säilinud metsaga 1926. aastal.

ly 85 ha. Of that number, the town of Tallinn had sold 43.7 ha to shipyards $(1 / 3$ of the plot already logged) and 10.9 ha to the port named after Peter the Great (that plot was not yet logged). Since the actual size of the forestland was 104 ha, apparently not all of the forest established was registered as forestland. Furthermore, some forest might have been felled in the initial years of World War I. The town of Tallinn officially owned 30.3 ha, which was made up of black alder stands of 30-100 years (Figure 3). Birch was represented as a secondary species, as was the predominantly 20-30-year-old spruce plantation.

The town wanted to fell 10.9 ha of forest in the part of land next to the graveyard logged in 1774 . The section primarily comprised old rot-infested black alders. The town, however, sought permission from the port master rather than from the Forest Protection Committee. The master did not mind, and the town logged 1.1 ha of forest in 1916/1917. The Forest Protection Committee launched an investigation and ascertained excessive felling by 0.1 ha. Due to the smallness of the area, the Committee did not declare the logging devastating and confined itself to a caution. The port master was summoned to explain whether he gave the permission proceeding from the interests of forest management or national defence (Sander \& Meikar, 2003).

Consequently, in spite of Kopli's rich history, widespread fame, forest plantation efforts and recreational value the destruction of the Kopli forests and the decline of Kopli as a recreation area failed to produce particular protests among the citizens. They were only deplored in belles-lettres. Poet Tõnis Sander (1887-1914) lamented the destruction in a poem dedicated to Kopli, "Telliskoppel", which was printed in the then press. In 1923, the poem was also published in T. Sander's collection "Õitsituled" ["Herdsmen's Night Fires"].

\section{Towns of Tartu and Pärnu}

Let us look at two more instances that might have developed into conflicts be- 
tween the citizens' understandings and the city government's intentions. The first relates to Tartu and Pärnu town forests and the second to the forests that once stood on Kopli Peninsula in the northwest of Tallinn. For various reasons, however, they did not lead to conflicts.

The $19^{\text {th }}$-century soil improvement works and systematic forest management arrangements brought about some minor changes. At the time, efforts were made to concentrate forests into more compact economic units, clearing smaller separate tracts of forestland elsewhere.

It is known that in 1882-1886 the Tartu Town Government started to vigorously reorganise the town's forest management system (Oettingen, 1886). One of the outcomes of the reorganisation was logging smaller isolated forests (followed by renting out the land as farmland) and forming larger, more compact forest areas (to which pasturelands and other kinds of lands were added, if necessary).
During the reorganisation, forest was felled on two separate tracts of land measuring 33 and 31 ha, which belonged to former municipal estates bordering on the town of Tartu.

The forests were felled and the tracts were rented out as farmland, which was more profitable in economic terms. This decision by the Town Government did not attract the attention of the public, the more so because the tracts fulfilled no recreational function for the townspeople. As at that time the state authority did not intervene in the affairs concerning private and municipal forests, the decision did not contravene the effective laws either. A few years later, when the 1888 Forest Protection Act of Russia was enforced, such a measure would probably have been more difficult to adopt in view of the scarcity of forests around Tartu.

Under the 1888 Forest Protection Act of Russia, the registered forests measuring more than 11 ha and, in particular, their

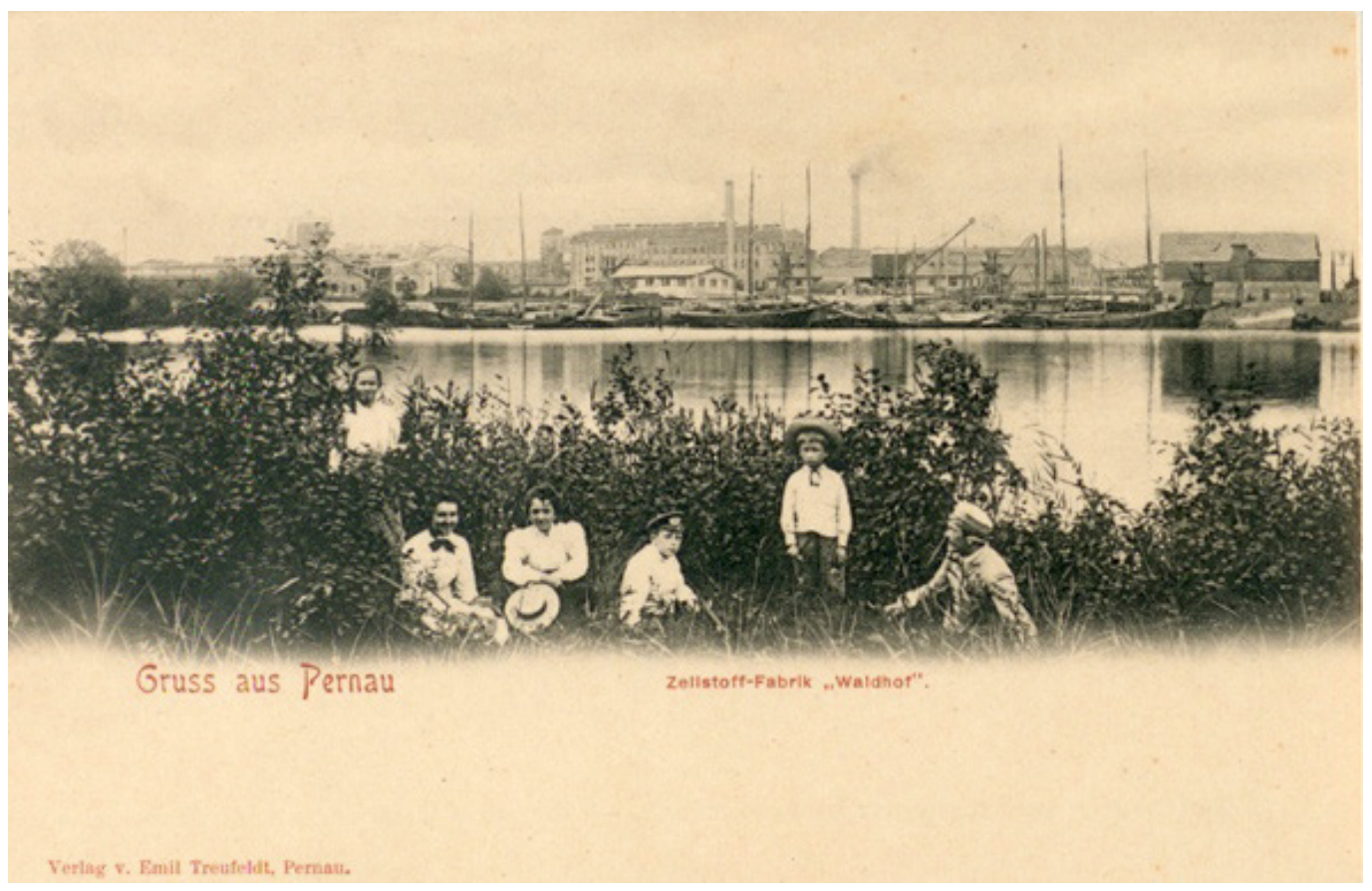

Figure 4. Waldof.

Joonis 4. Waldof. 
logging, were subjected to state supervision regardless of their form of ownership. In coastal regions, ground-protective forests were established on sandy areas along with a strict protection regime. Unauthorised transformation of forestland into farmland was forbidden, among other things. To gain permission, it was necessary to submit a well-reasoned application. Before making the decision, the Forest Protection Committee of a particular province took into account the forest cover percentage in the area, compensation for the land to be transformed (for instance, forestation of an inferior farmland), etc.

The transformation of forestlands into farmlands did not apply to urban forests, yet forests falling within or bordering on the administrative boundaries of major towns were vulnerable to the expansion of urban settlement and establishment of industrial enterprises. The first large-scale felling of forest in the town of Pärnu was occasioned by the setting up of the cellulose factory Waldhof in the last years of the $19^{\text {th }}$ century, when a 41-ha pine stand in the Reiu protection forest partly penetrating into the town's administrative precincts was allotted for industrial development. In the early $20^{\text {th }}$ century, 12 ha in the area were designated for a railway and a sandpit, followed in 1909 by a further 48 ha of the protection forest next to Waldhof, primarily for building dwellings for the factory workers (Figure 4). The total allotment, mostly related to the cellulose factory, was approximately 100 ha of pine forests growing on sandy areas, which made up $1 / 3$ of the original territory of the protection forest (EAA 5095.1.183; EAA 5095.1.186).

\section{Conclusion}

In view of the changes in the natural environment in Estonian cities in recent decades after the country regained its independence, especially in and around Tallinn, and taking into account the concentration of the population as well as clashes of different views on forestry, the issue of conflicts is very topical. The issue may be considered even too broad and deep and multi-level. Here, one would expect more mutual understanding and joint decision-making which is significant in the context of what has happened in the history of the world. It is important to understand that in different societies, the concept of nature (individual trees, green areas, parks and forests) versus the economy has always incited conflicts. There is nothing new here, but the gravity of the situation in each case depends on the readiness of the state or municipalities and various civic associations. It appears that "green" conflicts are nothing out of the ordinary; in Estonia they date back to the Middle Ages when the land here was grasped in the Christian cultural sphere of western Europe as a result of military invasion and diplomacy. Unfortunately, the volume of this article does not allow for longer discussion on the matter.

Controversies beginning from the Middle Ages about forest use in Estonian towns have been of very diverse nature. They have primarily stemmed from increased demand for timber versus the need for forest preservation. Occasionally, the controversies have been due to differences of opinion between town governments and the central government. At times, towns have resisted the central government and made their stand, while at other times they have conceded due to economic considerations. Typical in the latter regard is the case of the Kopli Forest in Tallinn, in which the town gave preference to economic benefit.

Controversies over urban vegetation have been of different kinds. Due to its geographical location, Estonia has belonged to the sphere of interest of various countries. Accordingly, the local towns and their vegetation have also suffered from wars. A contributing factor to this was that several towns were initially established as fortification towns and some of them (such as Tallinn) continued as such until the mid- 
$19^{\text {th }}$ century. All the above has had its effect on urban vegetation. In fact, the first major tree planting projects launched by Tallinn town authorities were performed on earthen fortifications - bastions, kirikuaedades ja eraaedades 17. sajandil - established to serve military purposes (Läänelaid \& Sander, 2004; Sander, 2019).

New understandings and standpoints emerged at the birth of urban vegetation in the late $18^{\text {th }}$ (the first boulevards) and early $19^{\text {th }}$ (the first parks) centuries (Sander, 1998). While the permanent citizenry, primarily Germans who made up the ruling class in towns, was more eager to embrace urban vegetation, the subsequent settlers swelling the towns in the $19^{\text {th }}$ century found it fairly hard to do. This is particularly true of Estonians moving to towns. As Estonians acquired better education, developed a greater national awareness and understood and embraced urban culture, however, they also changed their attitude towards urban vegetation. Estonians became a people guarding urban vegetation and fighting for its preservation. The process was no doubt facilitated by the first Estonian-language publications on urban vegetation issued in the early 1890s and the already more detailed studies of urban vegetation and urban forests published in 1920-1940.

Acknowledgements. The authors would like to thank Barbara Wardenburg from California, USA, for her tremendous help in compiling the article and for her initial English language revision.

\section{References}

\section{Publications}

Alamaa, E., Kivi, A. 1966. Tallinn: Settlement and Materials on Building History in Seven Volumes. (Tallinn: Linna asustus ja ehitusajaloolisi materjale seitsmes köites). Vol. 3 and 4. Tallinn, a manuscript in the Estonian Academic Library. 339 pp and 277 pp. (In Estonian).
Ayling, R.D., Kelly, K. 1997. Dealing with conclict: natural resources and dispute resolution. Commonwealth Forestry Review, 76(3), 182185.

Berger, U. 1988. Grim Fate - Paul Fleming's Love. (Ränk saatus, ehk Paul Flemingu armastus). Tallinn, Eesti Raamat. 157 pp. (In Estonian).

Falck, P.T. 1914. A Baltic citizen of old grist and grain. (Ein baltischer Bürger von altem Schrot und Korn). Riga, Verlag von Jonck \& Poliewsky. 77 pp. (In German).

Fleming, P. 1651. Spiritual and Secular Poetry. (Geist- und Weltliche Poëmata). Naumburg, C. Forbergers Witwe. 670 pp. (In German).

Hallas, K. 1995. Estonian in a metropolis. (Eestlane ja suurlinn). - Kunstiteaduslikke Uurimusi, 8, 90-116. (In Estonian with German summary).

Helk, V. 1977. The Jesuits in Dorpat (1583-1625): An Outpost of the Counter-Reformation in NorthEastern Europe. (Die Jesuiten in Dorpat (15831625): Ein Vorposten der Gegenreformation in Nordosteuropa). Odense, Odense University Press. 335 pp. (In German).

Hellström, E. 1996. Environmental forestry conflicts, forest policies and the use of forest resources: recent developments in USA, Germany, France, Sweden, Finland and Norway. - EFI Working Paper 7. Joensuu, European Forest Institute. 72 pp.

Hunter, I.R. 2001. What do people want from urban forestry? - The European experience. - Urban Ecosystems, 5, 277-284. https://doi. org/10.1023/ A:1025691812497.

Kala, T. 1998. Confirmation of the privileges of the city of Tallinn by King Erik Plovpenning of Denmark. (Bestätigung der Privilegien der Stadt Tallinn durch König Erik Plovpenning von Dänemark). - Vana Tallinn, VIII (XII), 20-22. (In German).

Kenkmaa, R., Vilbaste, G. 1965. Bastions and Greeneries of Tallinn. (Tallinna bastionid ja haljasalad). Tallinn, Eesti Raamat. 87 pp. (In Estonian).

Kirchner, J. 1855. Paul Fleming's Life and Poetry. First Part. (Paul Flemings Leben und Dichtungen. Erste Abteilung). Reval, Lindfors Erben. 86 pp. (In German).

Konijnendijk, C.C. 1999a. Urban forestry in Europe: a comparative study of concepts, policies and planning forforest conservation, management and development in and around major European cities. - Academic dissertation. Joensuu, University of Joensuu, Faculty of Forestry. 182 pp.

Konijnendijk, C.C. 1999b. Urban forestry: comparative analysis of policies and concepts in Europe. Contemporary urban forestry polici-making in selected cities and countries of Europe. - EFI Working Paper 20. Joensuu, European Forest Institute. 266 pp. 
Konijnendijk, C.C., Nielsen, A.B., Schipperijn, J., Rosenblad, Y., Sander, H., Sarv, M., Mäkinen, K., Tyrväinen, L., Donis, J., Gundersen, V., Åkerlund, U., Gustavsson, R. 2007. Assessment of urban forestry research and research needs in Nordic and Baltic countries. - Urban Forestry \& Urban Greening, 6(4), 297-309. https://doi.org/10.1016/j.ufug.2007.08.001.

LUB = Bunge, F.G. 1853. Livonian, Estonian and Courland Documents. First Volume (1093-1300). (Liv-, Esth- und Curländisches Urkundenbuch. Erste Band (1093-1300)). Reval, Kluge \& Ströhm. 188 pp. (In German).

LUB = Bunge, F.G. 1855. Livonian, Estonian and Courland Documents. Second Volume (1301-1367). (Liv-, Esth- und Curländisches Urkundenbuch. Zweite Band (1301-1367)). Reval, Kluge \& Ströhm. 830 pp. (In German).

LUB = Bunge, F.G. 1857. Livonian, Estonian and Courland Documents. Third Volume (1368-1393). (Liv-, Esth- und Curländisches Urkundenbuch. Dritte Band (1368-1393)). Reval, in Commission bei Kluge und Ströhm. Druck von Heinr. Laakmann in Dorpat. Reval, Kluge \& Ströhm. 202 pp. (In German).

Loorits, O. 1990. The Worldview of Estonian Folk Religion. (Eesti rahvausundi maailmavaade). Tallinn, Perioodika. 79 pp. (In Estonian).

Läänelaid, A., Sander, H. 2004. History and age of old limes (Tilia spp.) in Tallinn, Estonia. Konijendijk, C.C., Schipperijn, J., Hoyer, K.K. (eds.). Forestry Serving Urbanised Societies. Vienna, IUFRO, 267-280.

Magnus, R., Sander, H. 2019. Urban trees as social triggers: The case of the Ginkgo biloba specimen in Tallinn, Estonia. - Sign Systems Studies, 47, 234-256.

Meikar, T. 1997. Some stages of the history in the management of forests of the Naissaar Island. - Martin, J., Pärn, H. (eds.). Naissaar: Nature and Nature Conservation: Naissaar, Nargen, Nargö, Terra feminarum. Tallinn, International Center for Environmental Biology, 39-51.

Meikar, T. 1998. The forest of Naissaar and man. - Talvi, Tiina (ed.). Nature Conservation in a Europe of Unification. Kuressaare, Publication of the West-Estonian Biosphere Reserve, 225-239.

Meikar, T. 2002. The castle park of Haapsalu in the turmoil of privatization. - Proceedings of the Läänemaa Muuseum, VI, 69-83. (In Estonian with English summary).

Meikar, T., Sander, H. 1996. The activity of the head foresters of Tallinn in field of the urban forestry in the years 1864-1944. (Tallinna metsaülemad linnametsanduse arendajatena aastatel 1864-1944). - Eensaar, A., Sander, H. (eds.). Human Impact on the Environment of Tallinn. (Inimmõju Tallinna keskkonnale) III. Tallinn, Tallinn Botanic Garden, 194-199.

Meikar, T., Sander, H. 2000. Forestry in the city of Tallinn/Reval - a historical approach. (Die Forstwirtschaft in der Stadt Tallinn/Reval ein historischer Zugang). - Allgemeine Forstund Jagdzeitung, 171, 124-132. (In German).
Meikar, T., Sander, H. 2001. The history of the forests of the town of Tallinn. (Tallinna linna metsad läbi ajaloo). - Estonian Forests and Forestry at the Turn of the Millennium. (Linnametsad ja linnametsandus Eestis). Tartu, Proceedings of the Academical Forestry Society XVI, 37-53.

Nottbeck, E. 1884. Old Real Estate in Reval. (Der alte Immobilienbesitz Revals). Reval. 86 pp. (In German)

Oettingen, G. von. 1886. Review of the Activities of the Municipal Administrative Period of 1882-1886. (Rückblick auf die Thätigkeit der städtischen Verwaltungsperiode 1882-1886). Riga, Stahl. 13 pp. (In German).

Pabst, E. 1873. The Reval Rose Garden. Contributions to Visitors of Estonia, Livonia, and Courland. (Der Revaler Rosengarten. - Beiträge zur Kunde Ehst -, Liv -, und Kurlands). Reval, Verlag von Lindfors' Erben, 260-288.

Pilliroog, E. (comp.). 1997. The Church and Congregation of Kaarli. (Kaarli kirik ja kogudus). Tallinn, EELK Tallinna Toompea Kaarli kogudus. 256 pp. (In Estonian).

Pullat, R. (ed.) 1969. The History of Tallinn Since the Beginning of the 1860s Until the Year 1965. (Tallinna ajalugu XIX sajandi 60-ndate aastate algusest 1965. aastani). Tallinn, Eesti Raamat. 430 pp. (In Estonian with English summary).

Pullat, R. (ed.) 1976. The History of Tallinn Until the Year 1860. (Tallinna ajalugu 1860-ndate aastateni). Tallinn, Eesti Raamat. 430 pp. (In Estonian).

Punning, J.-M., Koff, T., Ratas, U., Tann, R. 1998. Shoreline displacement and vegetation history on island Naissaar, Baltic Sea. - Journal of Coastal Research, 14, 933-938.

Ratas, R. 1997. Nature protection in Estonia: historic approach. - Martin, J., Pärn, H. (eds.). Naissaar: Nature and Nature Conservation: Naissaar Nargen, Nargö Terra Feminarum. Tallinn, International Center for Environmental Biology, 4-8.

Russow, E. 1862. Flora of the Area Surrounding Reval. (Flora der Umgebung Revals). Dorpat, Heinrich Laakmann. 122 pp. (In German).

Sander, H. 1998. Research on urban forests and urban trees in Estonia - A historical and the present situation. - Sander, H., Randrup, T.B. (eds.). Urban Forestry in the Nordic and Baltic Countries. - Proceedings of a Nordic Workshop on Urban Forestry, Estonia, Dec. 1997. Tallinn/Copenhagen, 5-17.

Sander, H. 2001a. Historical description green belt of the around old Tallinn. (Tallinna vanalinnaga piirneva haljastusvööndi ajalooline õiend). Manuscript in Ecological Development and Planning. Tallinn, Department of Tallinn City Government. 98 pp. (In Estonian).

Sander, H. 2001b. The history and present state of verdure in Haapsalu. - Proceedings of the Läänemaa Museum, V, 128-151. (In Estonian with English summary). 
Sander, H. 2019. The city of limes. (Pärnade linn). - Sirp, 30, 6-7. (In Estonian).

Sander, H., Levald, A., Meikar, T. 2005. Problems of small-scale forestry in the urban changing environment of Estonia. Mizaras, S. (ed). Small-scale Forestry in a Changing Environment. - Proceedings of the International Symposium IUFRO, Research Group 3.08.00 Small-scale Forestry, Lithuania, May/June 2005. Vilnius, 191-199.

Sander, H., Meikar, T. 1996. Father and son Kühnert - forestry and horticulture pioneers in Estonia. (Vater und Sohn Kühnert - Pioniere der Forstwirtschaft und des Gartenbaus in Estland). - Allgemeine Forst- und Jagdzeitung, 167, 116-121. (In German).

Sander, H., Meikar, T. 1997. The forests of Naissaar from the 13th to the 19th Century. - Proceedings of the Academic Forest Society VII. A Brief Overview of the 700-Years' History of the Island of Naissaar near Tallinn, 15-25. (In Estonian with English summary).

Sander, H., Meikar, T. 2000. The significance of the law of King Erik VI Menved of Denmark from 1297 to the forests of the nearby islands off Reval/Tallinn (Estonia). (Die Bedeutung des Gesetses von König Erik VI Menved von Dänemark aus dem Jahre 1297 für die Wälder der Nahegelegenen Inseln vor Reval/ Tallinn (Estland)). - Archiv für Naturschutz und Landschaftsforschung, 39, 253-265. (In German).

Sander, H., Meikar, T. 2003. History of the cultural area Lustwald, a paddock forest of Reval/ Tallinn (Estonia) situated in northeastern Europe. (Geschichte des Kulturraum Lustwald Europa liegenden Nordöstlichen Koppelwaldes von Reval/Tallinn (Estland)). - Archiv für Naturschutz und Landschaftsforschung, 42, 51-64. (In German).

Sander, H., Meikar, T. 2015. On the development of parks in Tallinn - the case of Falkpark. (Kuidas kujunesid Tallinna pargid - Falgi pargi lugu). - Vana Tallinn, 26 (30), 104-141, 281-283.
Sander, H., Randrup, T.B. (eds.). 1998. Urban forestry in the Nordic and Baltic Countries. - Proceedings of a Nordic Workshop on Urban Forestry, Estonia, Dec. 1997. Tallinn/ Copenhagen. 77 pp.

Schreinert, K. 1937. Hans Moritz Ayrmann's travels through Livonia and Russia in 16661670. (Hans Moritz Ayrmanns Reisen durch Livland und Russland in den Jahren 16661670). Tartu, K. Mattiesen. 61 pp. (In German).

Sutcliffe, A. (ed.) 1980. The Rise of Modern Urban Planning 1800-1914. London, Marsell. 235 pp.

Tarand, A. 1984. Impressions of urban greenery on the basis of Tallinn. (Linnarohelusest Tallinna muljetel). - Eesti Loodus, 8, 99-506. (In Estonian with English summary).

Tarand, L. 1975. H.H. Falck. One of Tallinn's first arborists. - Estonian Nature, 18(10), 593-594. (In Estonian with English summary).

The Chronicle. 1988. The Chronicle of Balthasar Russow: A Forthright Rebuttal Errors and Mistakes of Balthasar Russow. Madison, Baltic Studies Center. 289 pp.

Vende, V. 1990. Forgotten Tallinn: a Walk Around the Old Town. (Ununenud Tallinn: jalutuskäik ümber vanalinna). Tallinn, Perioodika. 93 pp. (In Estonian).

Zobel, R. 2001. Tallinn (Reval) in the Middle Ages. Town Building in the 13 th- $14^{\text {th }}$ Centuries. Tallinn, Estonian Academy of Arts. 215 pp. (In Estonian with English summary).

\section{Archive sources}

EAA 5095.1.183. Отчет об устройстве лесозащитной дачи им. Рейдегоф.

EAA 5095.1.186. Дело о разрешении исключения 44, 22 дес. лесной площади из Рейденгофского защитного леса под застройку города Пернова. 


\section{Linnametsadega seotud konfliktide ajaloost Eestis}

\section{Heldur Sander ja Toivo Meikar}

\section{Kokkuvõte}

Artiklis on käsitletud Eesti linnametsade käekäigu muutusi ja nendega seotud konfliktide ajalugu, samuti juhtumeid, kus olid eeldused konfliktide tekkeks, kuid teatud põhjustel jäid need ära.

Eestlastele omaseks said linnad 19. ja eriti 20. sajandil. Selle sajandivahetuse linnade arengut on vaadeldud mitte rahvuslikul, vaid internatsionaalsel tasandil, sest industraliseerumine ja urbaniseerumine olid oma olemuselt rahvusvahelised protsessid, nii ka Eestis.

Tallinna lähissaare Naissaare mets. Saar oma metsaga oli juba arvatavasti 9 . sajandist maamärk ning hiljem on siinset metsa hoitud vana tava järgi. 17. juunil 1297. aastal Taani kuninga Erik VI Menvedi allkirjastatud ürikus täpsustati saare kuuluvust ning sel ja linnalähistel väikesaartel keelati metsaraie. Kuni 17. sajandi keskpaigani kasutati Naissaare metsi mõõdukalt Tallinna linnarae järelevalvel, et rahuldada linna puiduvajadust. Sealset metsa siiski rüüstati, kuid tervikuna mets säilis.

Kindlustuste rajamise ja sõjaliste käikudega seotud juhtumid. Tallinna arengut on mõjutanud asjaolu, et linn on olnud aastasadu kindluslinn. Sõjaliste sissetungide kartuses hävitati aedadega eeslinnu ning sellest tulenesid vastuolud elanike, linnavalitsuse ja linnas paikneva sõjaväe juhataja vahel. Esimene sellekohane teade on 16. sajandist, mil Liivi sõjas hävines 14. sajandist pärit Suurgildile kuulunud Roosiaed kindlustustööde ja Tallinna piiramiste tõttu. Samuti hävitati linnamüüri taga paiknenud viljapuude, marjapõõsaste ja lillede, väikeste suvemajade ja lehtlatega aedu 17. sajandi teisel poolel muldkindlustuste (bastionide) rajamisel. Põhjasõja puhkemisel nõuti tollal Rootsile kuulunud Tal- linnas kindlustusvööndi eeslinnades kõigi majade lammutamist, aedade hävitamist ja suurte puude maharaiumist. Sarnaselt oli see Tallinnas Krimmi sõja (1853-1856) ajal. Dessandi kartuses Soome lahel ristlevatelt Inglise-Prantsuse sõjalaevadelt lõhuti maha 1854. aasta märtsis osa Kalamaja linnajaost. Hävitati elumajad, kõrvalhooned ja aiad ning raiuti maha suured puud ja osa linna põhjapoolsest puiesteest. Kõik need teguviisid põhjustasid linnaelanikes palju pahameelt ning sündmusi mäletati aastakümneid hiljemgi ja jäädvustati ka ajaloolistes allikates ja ilmunud kirjasõnas.

Tallinna Pirita Kloostrimetsa juhtum. Pirita jõe suudme lähedal asub 1400. aastal asutatud ning 1577. aastal purustatud Pirita kloostrile kuulunud Kloostrimets, mis hiljem läks Nehatu mõisale. Linn omandas Kloostrimetsa 1733. aastal Nehatu mõisa ostmisega. 1866. aastal tegi Kloostrimetsas linna metsaülem (1864-1883) Wilhelm Kühnert esimese metsakorralduse. 1875. aastal alustati seal metsaistutusega ja 1904. aastaks oli rajatud 94 ha metsakultuure, neist 28 ha varem kasega kaetud alale. Uus metsaülem (1883-1904) Adolph Müller soovis linna metsades arendada traditsioonilist metsamajandust. Linnavalitsuses maksvusele pääsenud uudsed ideed toetusid arusaamale, et linnalähedased metsad peavad kandma ka puhkemajanduslikku funktsiooni, mille juures puiduproduktsioon oli kõrvalnähtus. 1893. aasta Mülleri uue metsakorralduse alusel hakati likvideerima üleseisnud mände, ent see tekitas ajakirjanduses tugeva protestilaine ja linnavalitsus keelas raied. 1903. aasta Kloostrimetsa metsade majanduskava nägi ette metsakasutuse tunduvat intensiivistamist ja aastalangi pindala suurendamist 2,9 hani. Linnavalitsus seda ei kinnitanud ja eri- 
nev nägemuse tõttu metsade majandamises lahkus metsaülem Müller 1904. aastal ametist.

Tallinna Falgi pargi juhtum. 1850. aastatel omandas Toomgildi oldermann Hans Heinrich Falck (1791-1874) bastionivööndi äärsel alal 1,6 ha suuruse maatüki, kuhu rajati looklevate teeradadega ja puudega park. 1860. aastaks valmisid muusikapaviljon ja restoran, tegutses erinevaid lõbustusasutusi ja peeti meelelahutuslikke ettevõtmisi. 1868. aasta kinkelepinguga kinkis Falck oma aia ja hooned Toomgildile nõudega, et need jääksid avalikku kasutusse. Seda nõuet ei täidetud, ala renditi välja ja seda kasutati mitmesugustel eesmärkidel. 20. sajandi algul soovisid mõned linnavalitsuse liikmed muuta park avalikuks haljasalaks. Paraku see ei õnnestunud, rentnikud kaebasid 1911. aastal Tallinna ringkonna kohtusse, kus protsessi võitis linnavalitsus. Rentnikud kaebasid asja edasi tollasesse Venemaa pealinna Sankt Peterburgi, kus ajaolud jäid venima, sest ei olnud selge, kellele ametlikult kuulus pargi alla jääv maa. Keeruliste aegade tõttu jäi selgus saamata. Lahendust ei toonud ka 1918. aastal Eesti vabariigi loomine ning segadused jätkusid ja park sai linnale ja avalikuks kasutamiseks alles 1930. aastatel.

Haapsalu Lossipargi juhtum. 19. sajandil sai krahv Pontus von Brevern De la Gardie mitmete juriidiliste aktide kaudu õigusliku staatusega lossipargi hõlmanud kinnistu uueks omanikuks. Tema poeg Nikolai soovis kinnistada eri omandivormide vahel täpset piiri, et saaks osa maatükist eraldada ja müüa. Samuti oli ta nõustunud müüma piirkonna osalise kõrge haljastusväärtusega ala linnale, kuid viimasel puudusid selle ostmiseks vajalikud rahalised võimalused. Kinnisvararegister käsitles seda juriidiliselt lõhestatud maatükki ühe üksusena, millel puudus täpne sisemine jagunemine. Linna seisukohalt olulise haljasala omanik soovis selle osaliselt majade ehitamiseks müüa. 20. sajandi alguses oli krundi suurus 10,3 hektarit, millest 8,2 oli eraomandis ja 2,1 renditud munitsipaalo- mand. Tuli otsustada kahe linnaarenduse mõiste vahel: säilitada suvekuurordi jaoks oluline haljasala või tihendada kesklinna hoonestust. Linnavalitsus toetas teist alternatiivi ja pärast ajalooliste dokumentide uurimist leiti võimalused krahvi omandiõiguste vaidlustamiseks ja kogu krundi käsitlemiseks linna omandina. Omanik kaebas aga asja kohtusse ja Haapsalu linn sai 1924/1925. aasta kohtumenetluses lüüa, misjärel suurem osa haljasalast tükeldati. Lossipargi vanem osa säilis, kuid on kaotanud endise ilme.

Järgnevad juhtumid on seotud linnametsade hävitamise ja maa-alade funktsioonide muutustega, neist ei kujunenud otseselt ühiskondlikke sotsiaalseid konflikte.

Tallinna Kopli poolsaare juhtum. Oma mitmekesise pinnareljeefi, vaheldusrikaste tammesalude ja kauni mereranna poolest oli see ala üks kaunimaid kohti Tallinna ümbruses. Ajaloost oli see tuntud Linnakopli või Telliskoplina. Esimene nimi tuli sellest, et maa-ala kasutati loomade karjamaana ning 14. sajandil rajatud tellisetehasest. Kopli poolsaarel leidus rohkesti metsa, selle kasutamispiirangud teenisid eelkõige linna kui esmakasutaja huve, kes sai siit linnamajandusele ja -kaitsele vajalikku puitu sadamaehitiste, fortifikatsioonitööde, veemajanduse jm tarbeks. Kopli mets kuulus linnale, 1912. aastal müüdi või renditi siin suured maa-alad laevatehaste ja sõjasadama ehitamiseks, 104 ha suurusest metsast säilis 33 ha. Loodi uudne infrastruktuur, ehitistega teenis linn rendiraha, tekkisid uued töökohad jne. Kõige selle tõttu ei kujunenud metsade kaoga konfliktsituatsiooni.

Tartu juhtum. On teada, et aastatel 1882-1886 asuti Tartu linnavalitsuses energiliselt reorganiseerima linna metsamajandust. Selle üheks väljundiks oli väiksemate eraldiseisvate metsade maharaiumine (maa renditi põllumajandusmaana välja) ja suuremate kompaktsete metsaalade moodustamine (siia lisati vajadusel karja- ja muid maid). Selle käigus raiuti maha Tartu 
linnaga piirnevate linnamõisate metsade kaks lahustükki pindaladega 0,33 ja 0,31 $\mathrm{km}^{2}$. Tegu oli Tartu linnavalitsuse otsusega, mis läks vastuollu seadustega, sest 1888. aastal kehtestatud metsahoiu seadusega pidanuks selleks taotlema üleriikliku Venemaa metsahoiukomitee nõusolekut. Raieluba ei taotletud ning nõusoleku saamine raieks nõudnuks argumenteeritud põhjendust, loa saamine oli raske, sest tegu oli metsavaese piirkonnaga.

Pärnu juhtum. Metsamaa ümberkujundamine põllumaaks ei kehtinud linnametsade kohta, kuid suuremate linnade halduspiiridesse jäävad või nendega piirnevad metsad olid haavatavad linnade asustuse laienemise ja tööstusettevõtete asutamise suhtes. Esimese ulatusliku metsa langetamise Pärnu linnas tõi kaasa tselluloositehase Waldhof rajamine 19. sajan- di lõpuaastatel. Linna halduskeskkonnas eraldati Reiu kaitsemetsas 41 ha suurune männikasvatus osaliselt tööstuse arendamiseks. 20. sajandi alguses määrati piirkonnas 12 ha raudtee ja muuks otstarbeks, millele järgnes 1909. aastal veel 48 ha kaitsemetsa Waldhofi kõrval põhiliselt tehase töötajatele mõeldud elamute ehitamiseks. Peamiselt tselluloositehasega seotud koguerand oli umbes 100 ha liivastel aladel kasvavaid männimetsi, mis moodustasid 1/3 kaitsemetsa algsest territooriumist.

Kokkuvõtteks. Eesti alal linnade kujunemisel tekkisid algusest peale mitmesugused konfliktid metsade kao, aedade ja haljastute hävitamisega sõjategevuse ja majanduse arengu käigus, millele aga vastandusid linnaelanike võitlused linnade loodusolude parandamise nimel. 